\title{
Diffüz alveoler hemoraji
}

\section{Diffuse alveolar hemorrhage}

Mehmet Sezai Taşbakan®

Ege Üniversitesi Tıp Fakültesi, Göğüs Hastalıkları Anabilim Dalı, İzmir, Türkiye

Öz

Diffüz alveoler hemoraj (DAH) pulmoner mikro-sirkülasyondan kaynaklanan, sıklıkla sistemik bir vaskülitin neden olduğu, alveol içine eritrosit birikmesidir. DAH etiyolojisinde immün ve non-immün nedenler sorumludur. Hemoptizi ve nefes darlığı en sık karşılaşılan klinik semptomlardır. Akciğer grafisinde bilateral buzlu cam dansiteleri izlenir. Hemogram, böbrek fonksiyon testleri ve immünolojik belirteçler tanıya yardımcı laboratuvar testleridir. Bronko-alveoler lavaj sıvısının makroskopik ve mikroskobik bulguları ile tanı konulur. Tedavisinde altta yatan hastalığın tedavisi yanı sıra, yüksek doz kortikosteroid başta olmak üzere immünsupresif tedavi önem taşır.

Anahtar Sözcükler: Alveoler hemoraji, anemi, bronkoskopi.

\begin{abstract}
Diffuse alveolar hemorrhage $(D A H)$ is accumulation of erythrocytes into the alveoli and is often caused by pulmonary microcirculation resulting in systemic vasculitis. Immune and non-immune causes are responsible for DAH etiology. Hemoptysis and dyspnea are the most common clinical symptoms. Bilateral ground-glass opacity is seen at chest $x$-ray. Hemogram, renal function tests and immunological markers are diagnostic laboratory tests. Diagnosis is made by macroscopic and microscopic findings of bronco-alveolar lavage fluid. Treatments of the underlying disease as well as immunosuppressive therapy especially high-dose corticosteroids are important in treatment of DAH.
\end{abstract}

Keyword: alveolar hemorrhage, anemia, bronchoscopy.

Tanım: Diffüz alveoler hemoraji (DAH) pulmoner mikrosirkülasyondan kaynaklanan, sıklıkla sistemik bir vaskülitin neden olduğu, alveol içine eritrosit birikmesidir.

Etiyoloji: DAH etiyolojisinde ANCA ilişkili vaskülitler, izole pulmoner kapilleritis, bağ dokusu hastalıkları, anti-glomerüler bazal membran hastalığı, anti-fosfolipit antikor sendromu, Behçet hastalığı gibi sıklıkla immün nedenler söz konusu olurken; kalp hastalıkları, koagülasyon bozuklukları, enfeksiyonlar gibi non-immün nedenler de söz konusudur $(1,2)$ (Tablo-1). Otuz dokuz immün alveoler hemoraji sendromunun incelendiği bir çalışmada, etiyolojide \%74,3 oranında başta granülomatöz polianjitis ve mikroskobik polianjitis olmak üzere ANCA-ilişkili

Sorumlu yazar: Mehmet Sezai Taşbakan

Ege Üniversitesi Tıp Fakültesi, Göğüs Hastalıkları Anabilim

Dalı, İzmir, Türkiye

E-posta: sezai72000@yahoo.com vaskülitler saptanmıştır (3). Kliniğimizde $24 \mathrm{DAH}$ olgusunun değerlendirildiği çalışmada 9 olguda $(\% 37,5)$ immün etiyoloji saptanırken, 16 olguda $(\% 62,5)$ non-immün etiyoloji saptanmıştır $(4)$.

Klinik: Hemoptizi, nefes darlığı en sık karşılaşılan klinik semptomlardır. Bu semptomlarla başvuran hastalara anemi, diffüz radyolojik pulmoner infiltrasyon ve hipoksemik solunum yetmezliği de eşlik ediyorsa DAH öncelikle akla gelmelidir.

Illk solunumsal semptomun başlamasında bu yana 11 günden az zaman geçmiş ise, halsizlik ya da kilo kaybı ve artrit semptomları var ise ve bu semptomlara günde 1 gramdan fazla proteinüri eşlik ediyorsa daha çok immün nedenli DAH düşünülmelidir (5). 
Tablo-1. Diffüz alveoler hemoraji (DAH) etiyolojisi.

\begin{tabular}{ll}
\hline İmmun DAH nedenleri & Non-immün DAH nedenleri \\
\hline ANCA-ilişkili vaskülitler & Kalp hastalıkları \\
Granülomatöz polianjiit & \multicolumn{1}{c}{ Sol ventrikül disfonksiyonu } \\
Mikroskopik polianjiit & Kapak hastalığı \\
$\quad$ Eozinofilik granülomatöz polianjiit & Enfeksiyonlar \\
İzole pulmoner kapillerit & İlaçlar \\
Antiglomerüler bazal mebran antikor sendromu & Akut solunumsal distrest sendromu \\
Bağ dokusu hastalıkları & İdiopatik pulmoner hemosiderozis \\
$\quad$ Sistemik lupus eritematoz & Koagülasyon bozuklukları \\
$\quad$ Romatoid artrit & Radyasyona maruziyet \\
$\quad$ İnflamatuvar miyozit & Çevresel maruziyet \\
Antifosfolipid antikor sendromu & Kokain inhalasyonu \\
Henoch-Schönlein purpurası & Kemik iliği transplantasyonu \\
IgA vasküliti & \\
Kriyoglobülinemik vaskülit & \\
Behçet hastalığı & \\
Akciğer transplantasyon rejeksiyonu & \\
Hipokomplementemik ürtikerial vaskülit & \\
İlaç ilişkili vaskülit & \\
Kemik iliği transplantasyonu & \\
\hline
\end{tabular}

Tanı: Klinik ve rutin laboratuvar incelemelerde $\mathrm{DAH}$ düşünülen hastalarda, koagülasyon testleri, böbrek fonksiyon testleri, c-anti-nötrofil sitoplazmik antikor (c-ANCA), PR3-ANCA, MPOANCA, anti-glomerüler bazal membran (antiGBM) antikor, antinükleer antikor, antisiklik sitrüline peptid antikorları, romatoid faktör, antifosfolipid antikoru, kreatinin kinaz, idrar sedimenti tetkikleri istenmelidir.

Radyolojik bulgular spesifik olmasa da akciğer grafisi ve toraks biligisayarlı tomografide bilateral buzlu cam alanlarının varlığı ve bu bulguya hemoglobin değerinde düşüklük eşlik ettiğinde alveoler hemoraji göz önünde bulundurulmalıdır (Şekil-1).

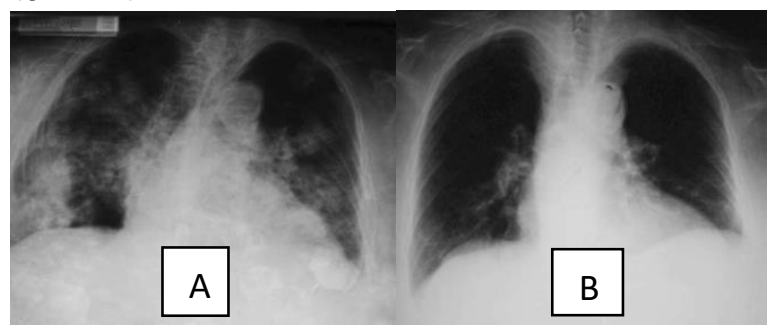

Şekil-1. Alveoler hemoraji olgusunun tanı anında (A) ve tedavi sonrasında (B) akciğer grafisi (1).

Tanıda bronkoskopi önemli rol oynamaktadır. Alveoler hemoraji kuşkusunun olduğu hastalarda bronko-alveoler lavaj (BAL) işlemi yapılmalıdır.
$\mathrm{Bu}$ işlem sırasında lezyonların en yoğun olduğu akciğer anatomik bölgesine bronkoskop aracılığı ile serum fizyolojik verilip geri aspire edilmektedir. Aspire edilen BAL sıvısının makroskopik olarak hemorajik özellikte olması alveoler hemorajiyi düşündüren önemli bir bulgudur (Şekil-2). Elde edilen hemorajik BAL sıvısının mikroskobik incelemesinde makrofajlarin \%2'sinden fazlasında hemosiderin fagosite edildiği (hemosiderin yüklü makrofaj) görülürse alveoler hemoraji tanısı doğrulanmaktadır (Şekil-3). Bronkoskopik akciğer biyopsisi de tanı için değerlendirilebilir, ancak çoğu hastada olan koagülasyon bozuklukları ve solunum yetmezliği nedeni ile genellikle işlemin güvenliği sınırlıdır.

Tedavi: İmmun nedenlerle ortaya çıkan DAH olgularında yüksek doz kortikosteroid tedavinin temelini oluşturmaktadır. Yüksek doz kortikosteroid yanında siklofosfamid ya da azatioprin gibi ikinci bir immünsupressif ajan da tedaviye eklenebilmektedir. Non-immün nedenlerle ortaya çıkan DAH olgularının tedavisinde kortikosteroid tedavi yanında, altta yatan nedene yönelik tedavi (koagülasyon bozukluğunun düzeltilmesi, enfeksiyon tedavisi, kalp hastalığının tedavisi vb.) önem taşımaktadır.

Prognoz: Altta yatan hastalığın ve gelişen solunum yetmezliğinin şiddetine bağlı olarak DAH 
olgularında mortalite $\% 20-50$ arasında değişmektedir. İnvaziv mekanik ventilasyon gerekliliği, akut başlangıç, C-reaktif protein ve kreatinin yüksekliği, artmış APACHE-II skoru yüksek mortalite ile ilişkili bulunmuştur $(4,7)$.

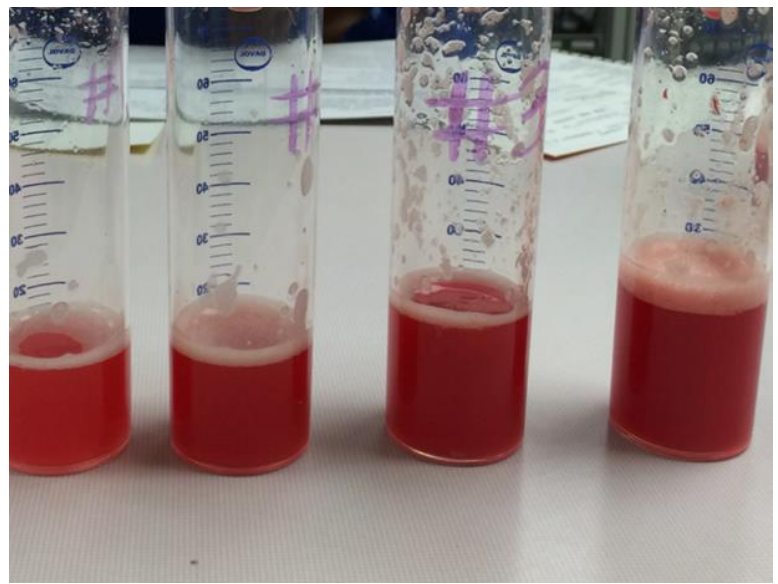

Şekil-2. Alveoler hemoraji olgusunun BAL Sıvısının makroskopik görünümü.

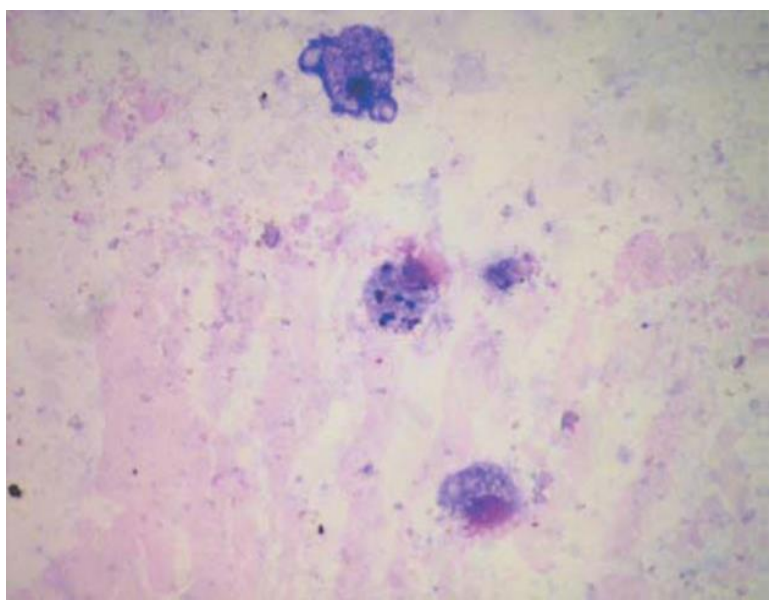

Şekil-3. Alveoler hemoraji olgusunun BAL Sıvısının mikroskobik incelemesinde hemosiderin yüklü makrofaj görünümü.

\section{Kaynaklar}

1. Taşbakan MS, Özdemir Ö, Yıldız BS, Özerkan F, Bacakoğlu F. Varfarin toksisitesi ve amiodaron tedavisi ile ilişkili iki alveoler hemoraji sendromu olgusu. Yoğun Bakım Dergisi 2010; 9 (1): 57-63.

2. Krause ML, Cartin-Ceba R, Specks U, Peikert T. Update on diffuse alveolar hemorrhage and pulmonary vasculitis. Immunol Allergy Clin North Am 2012; 32 (4): 587-600.

3. Quadrelli S, Diana D, Solis M, et al. Immune diffuse alveolar hemorrhage: clinical presentation and outcome. Respiratory Medicine 2017; 129: 59-62.

4. Gürgün A, Köşker P, Susur A, et al. Diffüz alveoler hemoraji sendromlarında mortaliteyi etkileyen faktörler. Türkiye Klinikleri Arch Lung 2009; 10 (2): 39-44.

5. Picard C, Cadranel J, Porcher R, et al. Alveolar haemorrhage in the immunocompetent host: a scale for early diagnosis of an immune cause. Respiration 2010; 80: 313-20.

6. Lichtenberger JP, Digumarthy SR, Abbott GF, Shepard JA, Sharma A. Diffuse pulmonary hemorrhage: clues to the diagnosis. Curr Probl Diagn Radiol 2014; 43: 128-39.

7. Ednalino C, Yip J, Carsons SE. Systematic review of diffuse alveolar hemorrhage in systemic lupus erythematosus: focus on outcome and therapy. J Clin Rheumatol 2015; 21: 305-10. 